\title{
Sclerochronological records of Arctica islandica from the inner German Bight
} Valérie M. Epplé, ${ }^{1 *}$ Thomas Brey, ${ }^{2}$ Rob Witbaard,
Henning Kuhnert

$\left({ }^{1}\right.$ Research Center for Ocean Margins ( RCOM), P.O. Box 330440, 28334 Bremen, Germany; ${ }^{2}$ Alfred Wegener Institute for Polar-and Marine Research, Bremerhaven, Germany; ${ }^{3}$ Netherlands Institute for Sea Research, Texel, The Netherlands; ${ }^{4}$ Department of Geosciences, University of Bremen, Bremen, Germany)

Received 12 July 2004; revised manuscript accepted 16 December 2005

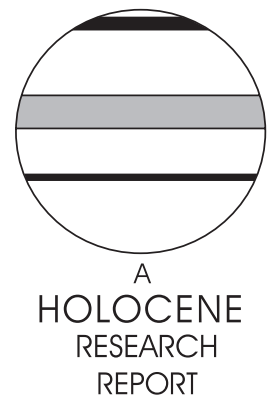

\section{Introduction}

Holocene palaeoclimatic reconstructions for the North Atlantic have been predominantly carried out using annually banded terrestrial proxies, such as tree-rings or ice-cores (Cook and Kariukstis, 1990; Luterbacher et al., 2002; Davies and Tipping, 2004). The increment of such proxy is controlled by environmental parameters and thus a time series of the proxy reflects historic environmental conditions. Little is known about the influence of the terrestrial climate on the marine realm. So far, palaeoclimatic marine conditions have been reconstructed mainly from oxygen isotope ratios obtained from the calcified annual density bands in tropical corals (Nozaki et al., 1978). As these organisms are not present in boreal-cold waters, sclerochronological analysis (measurement of the variable growth increments) of bivalves, has become more attractive for retrospective environmental studies of the North Atlantic (Jones, 1981; Richardson et al., 1981; Krantz et al., 1984).

The bivalve Arctica islandica (Linnaeus, 1767) is a particularly useful marine 'recorder', owing to its longevity of $>200$ years (Thompson et al., 1980) and its occurrence in the entire North Atlantic (Nicol, 1951). First studies on $A$. islandica were carried out on the continental shelves along the US coast

*Author for corresponding at: Am Müuerwald 12, 55120 Mainz, Germany (e-mail: vm_epple@yahoo.de)
(Jones, 1983; Weidmann et al., 1994; Marchitto et al., 2000) and later in the Baltic (Brey et al., 1990; Zettler et al., 2001) and North Sea (Witbaard et al., 1996; Schöne et al., 2003). In the North Atlantic, as well as in the North Sea Arctica deposits annual growth bands (Jones, 1983), which show similar growth patterns within a population (Witbaard and Duineveld, 1990; Marchitto et al., 2000). Shell growth is controlled by at least one environmental parameter, such as water temperature, salinity, food supply and dissolved oxygen. Knowing the functional relation between shell growth and the parameter allows the reconstruction of this parameter as well as of marine palaeo-environmental conditions based on shell growth time series. Depending on the study site and its hydrodynamics, the growth steering factors vary. Water temperature and food supply are commonly found to be the dominant growth factors in Arctica islandica from offshore sites (Weidmann et al., 1994; Witbaard et al., 1997; Schöne et al., 2003). In more shallow waters, sea surface salinity (SSS) has been regarded as an essential factor (Zettler et al., 2001).

In general, the climate variability in major parts of the Northern Hemisphere is dominated by the North Atlantic Oscillation (NAO), a climate oscillation that strongly influences winter temperature and precipitation in the North Atlantic region (Hurrell, 1995; Portis et al., 2001). The states of the NAO are measured by an index, defined as the pressure difference between the Azores and Iceland, reflecting the strength of the westerly winds across the Atlantic basin 
(Hurrell, 1995, 1996). The westerly winds also have an impact on the salinity content in the German Bight (Becker and Kohnke, 1978; Heyen and Dippner, 1998).

Compared with offshore environments, less is known about the ecology of Arctica inhabiting dynamic estuary-like habitats such as the German Bight. This study analyses whether Arctica islandica living in the dynamic nearshore habitat of the German Bight is a suitable proxy for environmental parameters that allows reconstruction of past environmental conditions from sclerochronological time series (shell growth chronologies).

\section{Study area}

The German Bight is a shallow marginal sea $(22 \mathrm{~m}$ average water depth) located in the southeastern part of the North Sea. Here, tides, wind, fluvial freshwater inflows and density differences cause a complex flow regime characterized by dynamic gradients and by large annual oscillations in salinity and water temperature (Mittelstaedt et al., 1983). In the southern German Bight, SSS ranges between $<25$ psu in spring to 35 psu in late summer (Schott, 1966; Sündermann et al., 1999), predominantly owing to the annual cycle in freshwater discharge of the rivers Elbe and Weser (Taylor and Stephens, 1980; Grabemann et al., 1983; Heyen and Dippner, 1998), which attain their maximum values in March-April (Elbe: $718 \mathrm{~m}^{3} / \mathrm{s}$, Weser: $327 \mathrm{~m}^{3} / \mathrm{s}$; Lenhart et al., 1996). Mean sea surface temperature (SST) varies between $2^{\circ} \mathrm{C}$ in February and $>18^{\circ} \mathrm{C}$ in August (Radach et al., 1995). Phytoplankton blooms occur in March/April and August (Reid et al., 1990; Edwards et al., 2001).

\section{Material and methods}

\section{Shell samples}

The eight shells of Arctica islandica used in this study were collected in May 2002 by a commercial fisherman with a beam trawl north of the East Friesian Island Spiekeroog in 15 to $20 \mathrm{~m}$ water depth along a transect of about $500 \mathrm{~m}$ length (Figure 1)

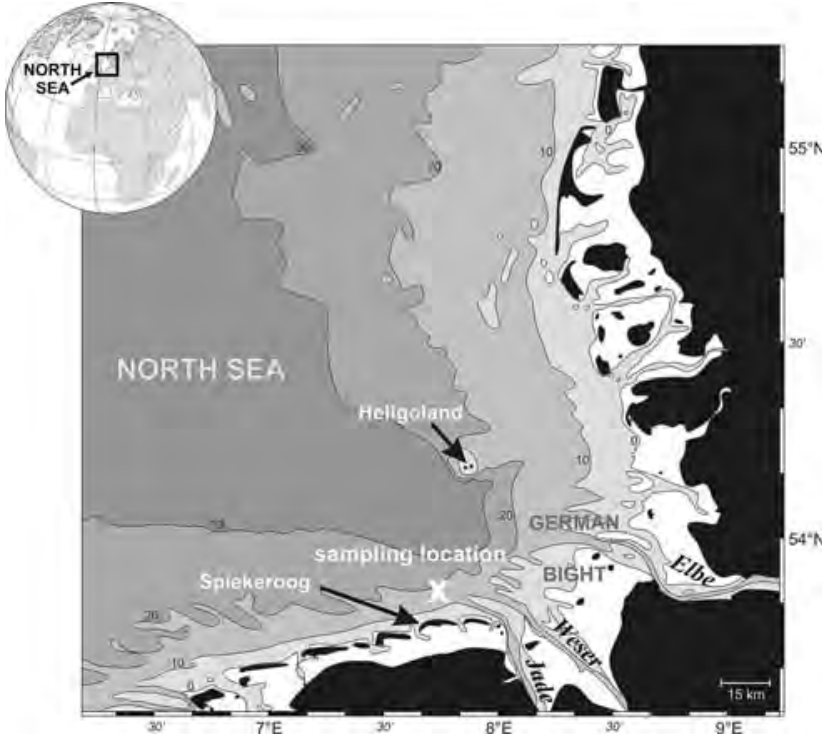

Figure 1 Bathymetric map of the German Bight showing the sample location of the bivalves

\section{Shell growth}

In $A$. islandica, a shell growth band increment represents the annual growth period (the amount of calcium carbonate deposited during the year). Each growth band increment is delimited by a growth line deposited in the colder winter months when shell deposition slows down or ceases (Merrill et al., 1961; Thompson et al., 1980) (Figure 2). Cross-sections and acetate peels were prepared of all left-hand valves following the method of Ropes (Ropes, 1985), additionally these cross-sections were etched with glutaraldehyde acetic acid (Mutvei et al., 1994) after peel preparation to improve readability of the growth bands increments. In each shell section subsequent growth bands increments were identified and measured under a microscope. As all specimens were caught alive, it was possible to assign a particular calendar year to every growth band increment. Two different statistical methods were used to remove the ontogenetic trend (decreasing band increment width with age) of decreasing width of

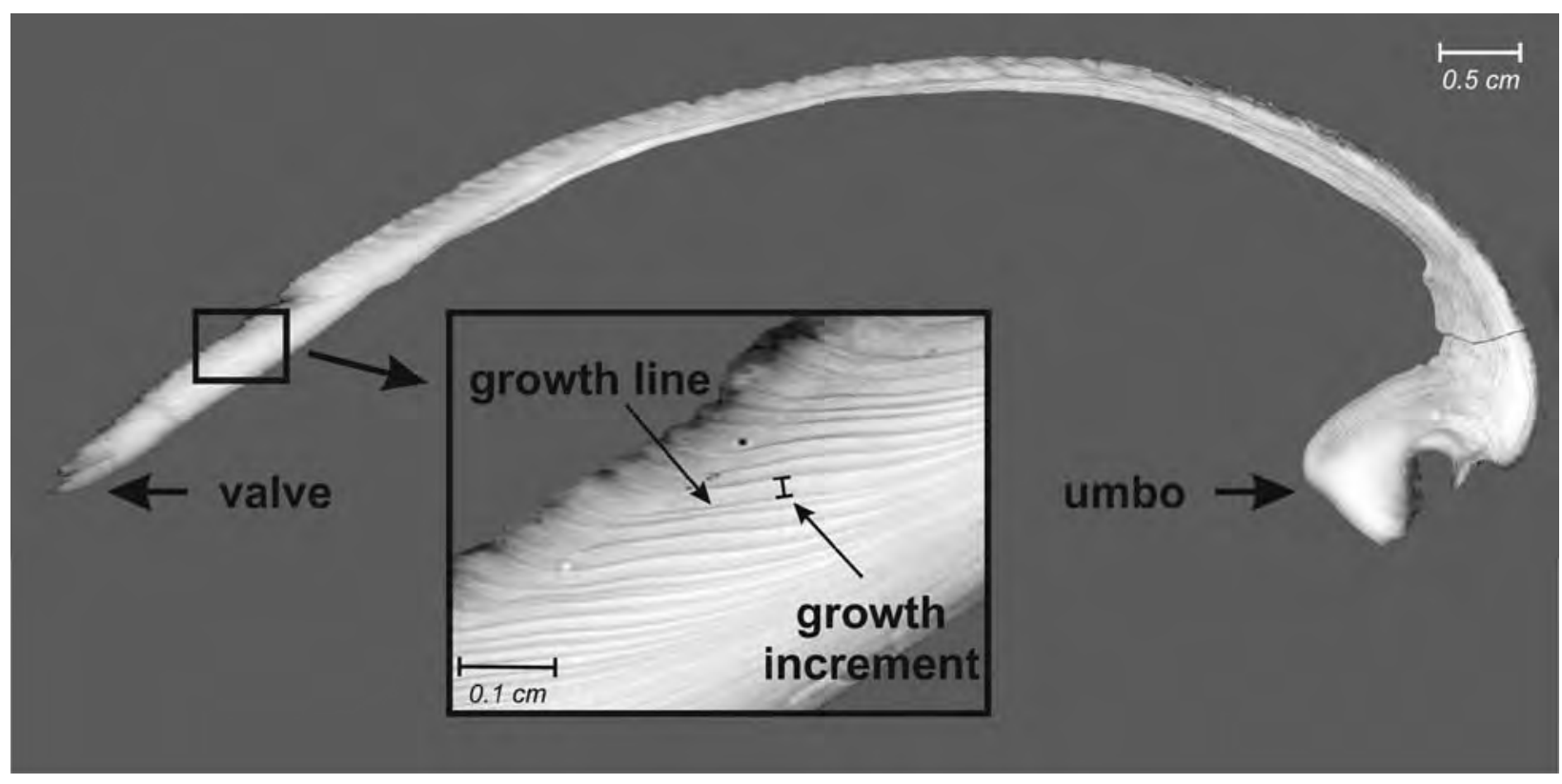

Figure 2 Cross-section of Arctica islandica from the German Bight with a shell length of $9.22 \mathrm{~cm}$ (from the outer shell to the umbo) 
growth increment $\mathrm{GI}_{i}$ width with age $i$ from the data. Standardized growth increments SGI were computed by (i) a 7-yr moving average filter (MAV)

$$
\mathrm{SGI}_{\mathrm{MAV}, i}=\frac{\mathrm{GI}_{i}}{\sum_{i-3}^{i+3} \overline{\mathrm{GI}_{i}}}
$$

and (ii) a simple exponent smoothing (SES) procedure:

$$
\mathrm{SGI}_{\mathrm{SES}, i}=\frac{\mathrm{GI}_{i}}{\mathrm{GI}_{i, \text { Predicted }}}
$$

where $\mathrm{GI}_{i, \text { Predicted }}$ is the estimate of a simple exponential function fitted to the growth increment series. Detrending of growth increments GI resulted in a standardized time index series for each specimen which indicate whether or not the annual standardized growth increment $\mathrm{SGI}_{\mathrm{MAV}}$ or $\mathrm{SGI}_{\mathrm{SES}}$,

\begin{tabular}{|c|c|c|c|c|}
\hline $\begin{array}{l}\text { Environmental } \\
\text { parameter }\end{array}$ & Time span & $\begin{array}{l}\text { Data } \\
\text { resolution }\end{array}$ & Recording location & Data source \\
\hline SST & $1880-2001$ & Monthly & Data field: 188 and 37 & $\begin{array}{l}\text { GISST, Version } 2.3 \mathrm{~b} \text { (http://www.metoffice.com/ } \\
\text { research/hadleycentre/obsdata/GISSI.html) }\end{array}$ \\
\hline \multirow[t]{3}{*}{ SST } & $1873-1881$ & \multirow[t]{3}{*}{ Monthly } & \multirow[t]{3}{*}{ Heligoland Reed (Isle of Heligoland) } & $\begin{array}{l}\text { Data provided by Federal Maritime and Hydrogra- } \\
\text { phical Agency, Hamburg, FRG (BSH) }\end{array}$ \\
\hline & $1883-1892$ & & & \\
\hline & $1960-1995$ & & & \\
\hline \multirow[t]{8}{*}{$\mathrm{SST}+\mathrm{SSS}$} & \multirow[t]{8}{*}{$1924-1988$} & \multirow[t]{8}{*}{ Annual } & $\mathrm{LV}$ Weser $53^{\circ} 52^{\prime} \mathrm{N} 07^{\circ} 50^{\prime} \mathrm{E}$ & $\begin{array}{l}\text { Light vessels (LV) positioned in the southern German } \\
\text { Bight data provided by Federal Maritime and } \\
\text { Hydrographical Agency, Hamburg, FRG (BSH) }\end{array}$ \\
\hline & & & LV Amrumbank $54^{\circ} 33^{\prime} \mathrm{N} 07^{\circ} 53^{\prime} \mathrm{E}$ & \\
\hline & & & LV Außeneider $54^{\circ} 13^{\prime} \mathrm{N} 07^{\circ} 18^{\prime} \mathrm{E}$ & \\
\hline & & & LV Borkumriff $53^{\circ} 44^{\prime} \mathrm{N} 06^{\circ} 24^{\prime} \mathrm{E}$ & \\
\hline & & & LV Elbe $154^{\circ} 00^{\prime} \mathrm{N} 08^{\circ} 07^{\prime} \mathrm{E}$ & \\
\hline & & & LV Elbe $453^{\circ} 56^{\prime} \mathrm{N} 08^{\circ} 40^{\prime} \mathrm{E}$ & \\
\hline & & & LV P11 / P8 54 $10^{\prime} \mathrm{N} 06^{\circ} 21^{\prime} \mathrm{E}$ & \\
\hline & & & LV P15 / P12 LV $54^{\circ} 00^{\prime} \mathrm{N} 07^{\circ} 51^{\prime} \mathrm{E}$ & \\
\hline \multirow[t]{6}{*}{ SSS } & $1873-1881$ & \multirow[t]{6}{*}{ Monthly } & \multirow[t]{6}{*}{ Heligoland Reed (Isle of Heligoland) } & \multirow[t]{6}{*}{$\begin{array}{l}\text { Data provided by Federal Maritime and Hydrogra- } \\
\text { phical Agency, Hamburg, FRG (BSH) }\end{array}$} \\
\hline & $1883-1886$ & & & \\
\hline & $1888-1893$ & & & \\
\hline & $1907-1919$ & & & \\
\hline & $1927-1944$ & & & \\
\hline & $1960-1995$ & & & \\
\hline Elbe river discharge & $1908-2000$ & Monthly & Gauge in Neu Darchau & $\begin{array}{l}\text { Data provided by Local Waterways and Shipping } \\
\text { Office, Lauenburg }\end{array}$ \\
\hline Weser river discharge & $1977-2000$ & Monthly & Gauge in Intschede & $\begin{array}{l}\text { Data provided by Local Waterways and Shipping } \\
\text { Office, Verden }\end{array}$ \\
\hline \multirow[t]{4}{*}{ Chlorophyll $a$} & $1975-1976$ & \multirow[t]{4}{*}{ Daily } & \multirow[t]{4}{*}{ East Friesian Isle of Norderney } & $\begin{array}{l}\text { Data provided by J.E.E. van Beusekom from } \\
\text { the Alfred-Wegener-Institut für Polar- und } \\
\text { Meeresforschung, Bremerhaven, Germany }\end{array}$ \\
\hline & $1978-1982$ & & & \\
\hline & $1984-1992$ & & & \\
\hline & $1994-2000$ & & & \\
\hline Chlorophyll $a$ & $1966-2000$ & & Heligoland Reed (Isle of Heligoland) & $\begin{array}{l}\text { Data published by Radach and Bohle-Carbonell } \\
\text { (1990) }\end{array}$ \\
\hline Chlorophyll $a$ & $1997-2002$ & Daily & $\begin{array}{l}54.097^{\circ} \mathrm{N}, 7.86^{\circ} \mathrm{E} \text { (in front of the Isle } \\
\text { of Spiekeroog) }\end{array}$ & $\begin{array}{l}\text { SeaWiFS (retrieved } 2 \text { May } 2006 \text { from http:// } \\
\text { daac.gsfc.nasa.gov/data/dataset/SeaWiFS) }\end{array}$ \\
\hline \multirow[t]{3}{*}{ Chlorophyll $a$} & $1966-1970$ & \multirow[t]{3}{*}{ Hourly } & & $\begin{array}{l}\text { Data provided by Federal Maritime and Hydrogra- } \\
\text { phical Agency, Hamburg, FRG (BSH) }\end{array}$ \\
\hline & $1974-1980$ & & & \\
\hline & $1985-2000$ & & & \\
\hline $\begin{array}{l}\text { Winter NAO index SL } \\
\text { (Station Lisboa) }\end{array}$ & $1864-2002$ & Annually & & $\begin{array}{l}\text { Data provided by Hurrell, (retrieved } 2 \text { May } 2006 \text { from } \\
\text { http://www.cgd.ucar.edu/cas/jhurrell/indices.html) }\end{array}$ \\
\hline $\begin{array}{l}\text { Winter NAO index PC } \\
\text { (principal component) }\end{array}$ & 1899-2002 & Annually & & $\begin{array}{l}\text { Data provided by Hurrell, (retrieved } 2 \text { May } 2006 \text { from } \\
\text { http://www.cgd.ucar.edu/cas/jhurrell/indices.html) }\end{array}$ \\
\hline
\end{tabular}

Table 1 List of environmental data sets used in the present study, including time span, measurement location and source 
respectively, during a particular year was above or below lifetime average $($ mean $=0, \mathrm{SD}=1)$.

From the eight standardized index series, a 163 -yr masterchronology was constructed by computing the average $\mathrm{SGI}_{\mathrm{MAV}}$ and $\mathrm{SGI}_{\mathrm{SES}}$ per calendar year. Synchrony among the eight standardized time index series was analysed by the running similarity statistics using a white noise order of 1 (retrieved 2 May 2006 from http://www.unifrankfurt.de/ grieser/dfg/ node $40 . \mathrm{html}$ ). Running similarity was assessed by the index $G$

$$
G(a, b, \ldots, m)=\frac{1}{n-1} \sum_{i=1}^{n-1}\left|\sum_{k=1}^{m} G a k, i\right|
$$

and

$$
G a, i=\left\{\begin{array}{rcc}
\frac{1}{m} & \text { if } & \Delta_{a, i}>0 \\
0 & \text { if } & \Delta_{a, i}=0 \\
-\frac{1}{m} & \text { if } & \Delta_{a, i}<0
\end{array}\right.
$$

where $\Delta_{a, i}$ is the difference in SGI of two successive years $\left(\Delta_{a, i}=\mathrm{SGI}_{i+1}-\mathrm{SGI}_{i}\right), n$ is the number of growth bands increments and $m$ the number of shells compared. The running similarity index $G$ ranges between 0 (perfect negative synchrony) and 1 (perfect positive synchrony).

A spectral density analysis (SAS-Institute, 2002) was applied to explore the 163-yr masterchronology for cyclic patterns.

\section{Environmental data}

Time series of available environmental data, such as SST, SSS, river discharge, precipitation, phytoplankton and atmospheric data, the NAO indices assumed to be relevant for the investigation area (the NAO indices assumed to be relevant for the investigation) were taken from published sources (Table 1). Unfortunately most data sets have gaps or cover a few years or decades at best.

\section{Relations between environmental data and shell growth chronologies}

Statistical relations between the $A$. islandica masterchronology and environmental data time series were analysed by correlation and partial correlation and subsequent construction of a multiple linear model (Deutsch, 2003). Owing to the large gaps in the SSS time series we decided to work with two data sets, one including SSS (55 years between 1908 and 1995) and one excluding SSS (83 years between 1908 and 2002).

\section{Results}

\section{Shell growth chronologies}

The age of the eight $A$. islandica specimens and hence the length of the shell chronologies ranged from 26 to 163 years covering the time span 2002-1840 (Figure 3). Synchrony between the growth patterns of the eight shells was very poor, as indicated by running similarity values between 0.30 and 0.64 (maximum overlap) and between 0.42 and 0.69 (26 year overlap), respectively (Table 2 ). Spectral density analyses indicates significant periodic components $(P<0.05)$ in the 163 -yr masterchronology with distinct peaks between 5 and 7 years (Figure 4$)$.

\section{Relations between environmental data and shell growth chronologies}

Correlations between the masterchronology and environmental parameter time series are poor, as no significant relation could be detected (Tables 3 and 4). Owing to the poor correlation, we abstained from the construction of a multiple linear model.

\section{Discussion}

The eight specimens analysed here show a low growth synchrony, as indicated by the running similarity values (Table 2, Figure 3). This is in contrast to the findings of Witbaard et al. (1996) and Schöne et al. (2003), who studied shells from offshore sites. We conclude that the poor synchrony results from the environmental conditions in the coastal sampling area. Situated just north of the Wadden Sea and within the Elbe-Weser estuary, this subtidal area is part of a highly dynamic region with extreme fluctuations in salinity, turbidity, temperature and other parameters. Tides in this area range between 3.5 and $6.2 \mathrm{~m}$ (Lassen and Siefert, 1991). North of the East Friesian Island Norderney tidal currents up to $>1 \mathrm{~m} / \mathrm{s}$ have been recorded (Umweltbundesamt, 1999). Tidal dynamics combine with wind-driven currents and river runoff dynamics. The Wadden Sea topography adds further spatial variability.

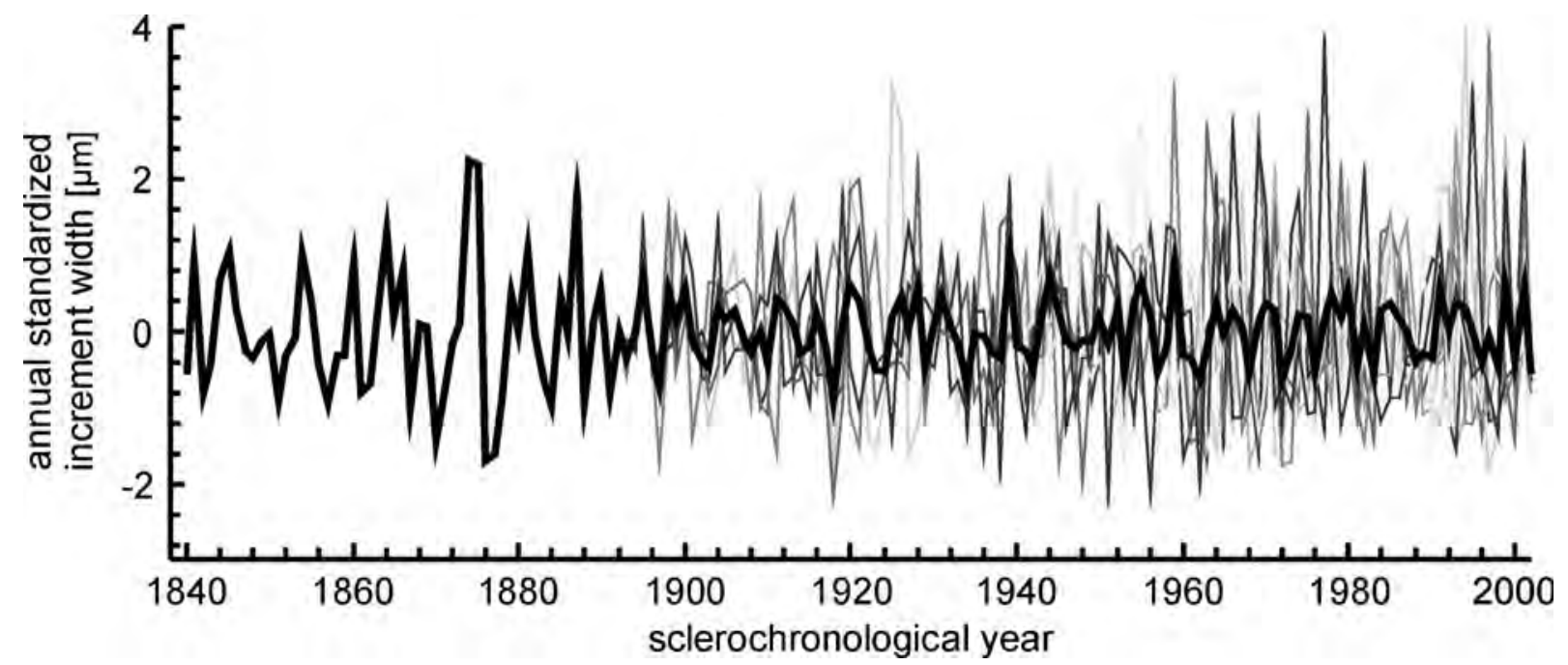

Figure 3 163-yr masterchronology (black line) of $A$. islandica. Grey lines indicate the eight standardized time index series the masterchronology is based on. Note that between 1840 and 1896 only one shell was available for the masterchronology, therefore amplitudes are higher than between 1896 and 2001 
Table 2 Pair-wise calculation of running similarity between the eight specimens for 26 years (1976-2002) below the diagonal and for the period of maximum overlap, that is, lifetime of the younger specimen, above the diagonal (moving average standardization technique). Overall running similarity of all eight shells over 26 years is 0.50

\begin{tabular}{|c|c|c|c|c|c|c|c|c|c|}
\hline Spec & SL (cm) Age (yr) & NSP 4 & NSP 5 & NSP 6 & NSP 7 & NSP 13 & NSP 17 & NSP 20 & NSP 24 \\
\hline NSP 4 & $\begin{array}{l}8.54 \\
60\end{array}$ & & 0.52 & 0.53 & 0.61 & 0.46 & 0.47 & 0.51 & 0.64 \\
\hline NSP 5 & $\begin{array}{l}9.22 \\
163\end{array}$ & 0.67 & & 0.43 & 0.39 & 0.58 & 0.52 & 0.53 & 0.47 \\
\hline NSP 6 & $\begin{array}{l}9.46 \\
106\end{array}$ & 0.69 & 0.48 & & 0.59 & 0.44 & 0.52 & 0.48 & 0.57 \\
\hline NSP 13 & $\begin{array}{l}6.41 \\
26\end{array}$ & 0.46 & 0.58 & 0.44 & 0.67 & & 0.46 & 0.58 & 0.58 \\
\hline NSP 17 & $\begin{array}{l}8.63 \\
63\end{array}$ & 0.54 & 0.67 & 0.49 & 0.58 & 0.46 & & 0.45 & 0.44 \\
\hline NSP 20 & $\begin{array}{l}8.44 \\
110\end{array}$ & 0.58 & 0.46 & 0.44 & 0.46 & 0.58 & 0.50 & & 0.51 \\
\hline
\end{tabular}

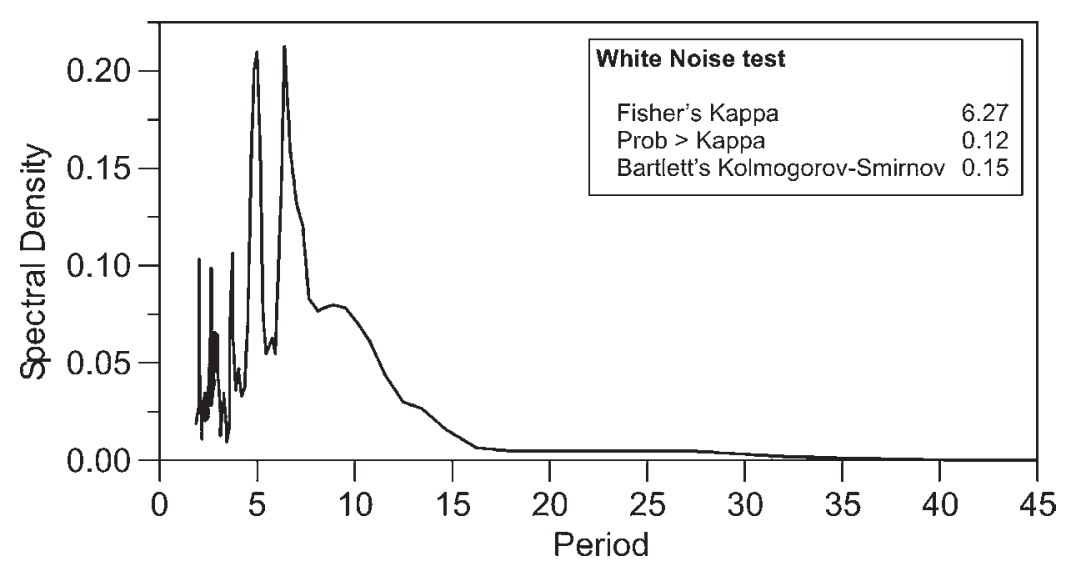

Figure 4 Spectral density analyses of the 163-yr masterchronology. The time series shows significant periodic components $(P<0.05)$. Note peaks between 5 and 7 years

Table 3 Correlations and partial correlations between environmental data (NAO, SST, Elbe river discharge and precipitation) and masterchronology of standardized growth increments SGI between 1908 and $2002(n=83)$. Coefficients in the first column refer to SGI and coefficients in the first row refer to $\mathrm{SGI}_{\mathrm{MAV}}$. No SSS data are available for this time span

\begin{tabular}{|c|c|c|c|c|c|c|}
\hline & Mean $\mathrm{SGI}_{\mathrm{MAV}}$ & NAO (PC) & SST & Elbe discharge (Spring) & Elbe discharge (Summer) & Precipitation \\
\hline \multicolumn{7}{|l|}{ Correlation matrix } \\
\hline Mean SGI SES & & 0.0084 & -0.0060 & -0.1113 & 0.0880 & 0.0140 \\
\hline NAO (PC) & -0.0322 & & $0.6498^{*}$ & -0.0119 & $-0.4009 *$ & -0.1613 \\
\hline SST & 0.0575 & $0.6498^{*}$ & & -0.0138 & $-0.4073^{*}$ & -0.0238 \\
\hline Elbe discharge (Spring) & -0.0357 & -0.0119 & -0.0138 & & $0.3899 *$ & $0.3939 *$ \\
\hline Elbe discharge (Summer) & 0.0232 & $-0.4009^{*}$ & $-0.4073^{*}$ & $0.3899 *$ & & $0.2351^{*}$ \\
\hline Precipitation & 0.0520 & -0.1613 & -0.0238 & $0.3939^{*}$ & $0.2351^{*}$ & \\
\hline \multicolumn{7}{|l|}{ Partial correlation matrix } \\
\hline Mean SGI & & 0.0065 & 0.0081 & -0.1820 & 0.1600 & 0.0632 \\
\hline NAO (PC) & -0.0669 & & $0.5810^{*}$ & 0.1427 & -0.1954 & -0.1873 \\
\hline SST & 0.1052 & $0.5810^{*}$ & & 0.0461 & $-0.2374 *$ & 0.1240 \\
\hline Elbe discharge (Spring) & -0.0703 & 0.1427 & 0.0461 & & $0.3838 *$ & $0.3507^{*}$ \\
\hline Elbe discharge (Summer) & 0.0515 & -0.1954 & $-0.2374 *$ & $0.3838^{*}$ & & 0.0525 \\
\hline Precipitation & 0.0528 & -0.1873 & 0.1240 & $0.3507 *$ & 0.0525 & \\
\hline
\end{tabular}

*Significant at $\alpha=0.05$. 
Table 4 Correlations and partial correlations between environmental data (NAO, SST, SSS, Elbe river discharge and precipitation) and masterchronology of standardized growth increments SGI between 1908-1919, 1927-1944 and 1960-1995 $(n=63)$. Coefficients in the first column refer to $\mathrm{SGI}_{\mathrm{SES}}$ and coefficients in the first row refer to $\mathrm{SGI}_{\mathrm{MAV}}$

\begin{tabular}{|c|c|c|c|c|c|c|c|c|}
\hline & $\begin{array}{l}\text { Mean } \\
\text { SGI }_{\text {MAV }}\end{array}$ & NAO (PC) & SST & $\begin{array}{l}\text { SSS } \\
\text { (Win-Spr) }\end{array}$ & $\begin{array}{l}\text { SSS } \\
\text { (Spr-Sum) }\end{array}$ & $\begin{array}{l}\text { Elbe discharge } \\
\text { (Spring) }\end{array}$ & $\begin{array}{l}\text { Elbe discharge } \\
\text { (Summer) }\end{array}$ & Precipitation \\
\hline \multicolumn{9}{|l|}{ Correlation matrix } \\
\hline Mean SGI ${ }_{\text {SES }}$ & & 0.0212 & -0.0118 & $0.0349 *$ & 0.0864 & 0.0870 & -0.0530 & 0.0095 \\
\hline NAO (PC) & -0.0900 & & $0.6953^{*}$ & -0.2404 & 0.0809 & -0.0440 & $-0.3906^{*}$ & -0.0986 \\
\hline SST & -0.0328 & $0.6953^{*}$ & & -0.2153 & -0.0410 & -0.0449 & $-0.3843^{*}$ & -0.0396 \\
\hline SSS (Win-Spr) & 0.1624 & -0.2404 & -0.2153 & & $0.5301 *$ & $-0.6127^{*}$ & $-0.3036^{*}$ & $-0.4107^{*}$ \\
\hline Elbe discharge (Spring) & -0.0231 & -0.0440 & -0.0449 & $-0.6127^{*}$ & $-0.5667 *$ & & $0.4872^{*}$ & $0.4746^{*}$ \\
\hline Elbe discharge (Summer) & 0.0715 & $-0.3906^{*}$ & $-0.3843^{*}$ & $-0.3036^{*}$ & $-0.6421^{*}$ & $0.4872 *$ & & 0.2044 \\
\hline Precipitation & -0.0231 & -0.0986 & -0.0396 & $-0.4107^{*}$ & $-0.3727^{*}$ & $0.4746^{*}$ & 0.2044 & \\
\hline \multicolumn{9}{|l|}{ Partial correlation matrix } \\
\hline Mean SGI & & -0.0045 & 0.0213 & 0.1026 & 0.0866 & -0.0712 & 0.1995 & 0.1035 \\
\hline NAO (PC) & -0.0116 & & $0.5658^{*}$ & -0.2554 & 0.0920 & 0.0196 & -0.1538 & -0.1453 \\
\hline SST & 0.0840 & $0.5658 *$ & & -0.0814 & $-0.3112^{*}$ & -0.0541 & $-0.3456^{*}$ & -0.0542 \\
\hline SSS (Spr-Sum) & 0.0203 & 0.0920 & $-0.3112^{*}$ & 0.1960 & & -0.1311 & $-0.5715^{*}$ & -0.1658 \\
\hline Elbe discharge (Spring) & 0.0114 & 0.0196 & -0.0541 & $-0.3844^{*}$ & & & 0.1962 & 0.2606 \\
\hline Elbe discharge (Summer) & 0.1160 & -0.1538 & $-0.3456^{*}$ & -0.0833 & -0.1311 & 0.1962 & & -0.2037 \\
\hline Precipitation & 0.1455 & -0.1453 & -0.0542 & -0.2137 & -0.1658 & 0.2606 & -0.2037 & \\
\hline
\end{tabular}

*Significant at $\alpha=0.05$.

The interaction of these factors may result in such small-scale variability in environmental conditions (eg, turbidity or food supply) that a strong random component is added to the growth pattern of each individual clam. The water temperature regime at shallow sites in the German Bight may be of particular significance. A. islandica is a temperate, cold water species (Cargnelli et al., 1999). The presumed temperature optimum for adults is about $6-16^{\circ} \mathrm{C}$, whereas temperatures $>20^{\circ} \mathrm{C}$ cause mortality (Merrill and Ropes, 1969). Water temperature in the German Bight can rise up to $18^{\circ} \mathrm{C}$ in summer, taking $A$. islandica close to its thermal limits. This may enhance the clam's sensitivity to other environmental stress or even induce growth reduction or cessation.

We could not detect a correlation between our masterchronology and time series of environmental parameters relevant for the North Sea and German Bight (Tables 3 and 4). This is in contrast to studies by Schöne et al. (2003), where a highly significant linear correlation occurred between annual growth rates of $A$. islandica from the central North Sea and the instrumental winter NAO index. They report that positive winter NAO conditions result in higher shell growth rates, because shell growth is largely controlled by food supply (Witbaard et al., 1997), which in turn is steered by winter NAO-induced forcing of atmospheric circulation.

Again, the dynamics of the nearshore German Bight may explain our results, although the spectral analysis of the 163-yr masterchronology indicated a cyclic pattern with distinct 5- and 7-yr periodicities, which are within the range of frequencies reported for instrumental winter NAO indices (Hurrell, 1995). Local variability in time and space obscure the large-scale superior parameters, thus preventing them from imprinting a clear signal on the clam growth history, and keeping synchrony of growth between specimens low, as discussed above.

\section{Conclusions}

High spatial and temporal environmental variability at our nearshore investigation site is assumed to be the major reason for the poor synchrony between specimens as well as between the masterchronology and time series of superior environmental parameters. The only way to check whether $A$. islandica from the German Bight does record large-scale superior parameters at all would be the analysis of many more individuals and of longer time series in order to cancel out the locally induced statistical noise. The spectral density analysis of the 163-yr masterchronology (Figure 4) indicates that it may be a worthwhile approach, because the distinct 5- to 7 -yr periodicity detected is within the range of frequencies reported for instrumental and proxy NAO indices.

\section{Acknowledgements}

We thank the fisherman G. Rowedder for providing the shell material analysed. For constructive reviews and comments on the English, which helped improve the article, B. Schramm, M. Trunzer, A. Jerkin, C. Wienberg and T. Felis are gratefully acknowledged. Thanks are also expressed to S. Kassner from the VU for helping with the shell scan. We also thank Milner and an unknown reviewer for their helpful comments and A. Dawson for his patience. This paper is a contribution to the Research Center for Ocean Margins, financially supported by the German Research Foundation (DFG).

\section{References}

Becker, G. and Kohnke, D. 1978: Long-term variations of temperature and salinity in the inner German Bight. Rapports et proces-verbaux des reunions/Conseil International pour l' Exploration de la Mer 172, 334-44.

Brey, T., Arntz, W.E., Pauly, D. and Rumohr, H. 1990: Arctica (Cyprina) islandica in Kiel Bay (Western Baltic): growth, production and ecological significance. Journal of Experimental Marine Biology and Ecology 136, 217-35.

Cargnelli, L.M., Griesbach, S.J., Packer, D.B. and Weissberger, E. 1999: Ocean Quahog, Arctica islandica, life history and habitat characteristics. NOAA Technical Memorandum NMFS-NE-148, $1-12$. 
Cook, E.K. and Kariukstis, A.L. 1990: Methods of dendrochronology - applications in the environmental sciences. Kluwer Academic Publishers and International Institute for Applied Systems Analysis, 394 pp.

Davies, A.L. and Tipping, R. 2004: Sensing small-scale human activity in the palaeoecological record: fine spatial resolution pollen analyses from Glen Affric, northern Scotland. The Holocene 14, 233-45.

Deutsch, H. 2003: Taschenbuch der Statistik. Wissenschaftlicher Verlag Harri Deutsch GmbH, 849 pp.

Edwards, M., Reid, P.C. and Planque, B. 2001: Long-term and regional variability of phytoplankton biomass in the northeast Atlantic (1960-1995). Ices Journal of Marine Science 58, 39-49. Grabemann, I., Krause, G. and Siedler, G. 1983: Langzeitige Änderung des Salzgehaltes in der Unterweser. Deutsche hydrographische Zeitschrift 36, 61-77.

Heyen, H. and Dippner, W.J. 1998: Salinity variability in the German Bight in relation to climate variability. Tellus 50A, 54556.

Hurrell, J.W. 1995: Decadal trands in the North Atlantic Oscillation: regional temperatures and precipitation. Science 269, 676-79.

- 1996: Influence of variations in extratropical wintertime teleconnections on Northern Hemisphere temperature. Geophysical Research Letters 23, 665-68.

Jones, D.S. 1981: Annual growth increments in shells of Spisula solidissima record marine temperature variability. Science 211, 165-67.

- 1983: Sclerochronology: reading the record of the molluscan shell. American Scientist 71, 384-91.

Krantz, D.E., Jones, D.S. and Williams, D.F. 1984: Growth rates of the sea scallop Placopecten magellanicus determined from the ${ }^{18} \mathrm{O} /{ }^{16} \mathrm{O}$ record in shell calcite. Biological Bulletin 167, 186-99.

Lassen, H. and Siefert, W. 1991: Mittlere Tidewasserstände in der südöstlichen Nordsee-säkularer Trend und Verhältnisse um 1980. Die Küste 52, 85-137.

Lenhart, J.H., Pätsch, J. and Radach, G. 1996: Daily nutrient loads of the european continental rivers for the years 1977-1993. Secondary Daily Nutrient Loads of the European Continental Rivers for the Years 1977-1993. Zentrum für Meeres- und Klimaforschung der Universität Hamburg, 159 pp.

Levitus, S. and Boyer, T.P. 1994: World ocean atlas. US Department of Commerce, Washington DC 4, 117 pp.

Linnaeus, C. 1767: Systema naturae par regna tria naturae. Salvii, $533-1327$.

Luterbacher, J., Xoplaki, E., Dietrich, D., Rickli, R., Jacobeit, J., Beck, C., Gyalistras, D., Schmutz, C. and Wanner, H. 2002: Reconstruction of sea level pressure fields over the Eastern North Atlantic and Europe back to 1500. Climate Dynamics 18, 545-61.

Marchitto, T.A., Jones, G.A., Goodfriend, G.A. and Weidman, C.R. 2000: Precise temporal correlation of Holocene mollusk shells using sclerochronology. Quaternary Research 53, 236-46.

Merrill, A.S. and Ropes, J.W. 1969: The general distribution of the surf clam and ocean quahog. Proceedings of the National Shellfish Association 59, 40-45.

Merrill, A.S., Posgay, J.A. and Nighy, F.E. 1961: Annual marks on the shell and ligament of sea scallop (Placopectan magellanicus). Fishery Bulletin 65, 299-311.

Mittelstaedt, E., Lange, W., Brockmann, C. and Soetje, C. K. 1983: Die Strömungen in der Deutschen Bucht. Secondary Die Strömungen in der Deutschen Bucht. Deutsches Hydrographisches Institut, $141 \mathrm{pp}$.

Mutvei, H., Westermark, T., Dunca, E., Carell, B., Forberg, S. and Bignert, A. 1994: Methods for the study of environmental changes using the structural and chemical information in molluscan shells. Bulletin de l'Institut océanographique Monaco 13, 163-91.
Nicol, D. 1951: Recent species of the Veneroid pelecypod Arctica Journal of Washington Academic Science 41, 102-106.

Nozaki, Y., Rye, D.M., Turekian, K.K. and Dodge, R.E. 1978: A 200 year record of carbon-13 and carbon-14 variations in a Bermuda coral. Geophysical Research Letters 5, 825-28.

Portis, D.H., Walsh, J.E., El Hamly, M. and Lamb, P.J. 2001: Seasonality of the North Atlantic Oscillation. Journal of Climate 14, 2069-78.

Radach, G. and Bohle-Carbonell, M. 1990: Strukturuntersuchungen der meteorologischen, hydrographischen, Nährstoff- und Phytoplankton-Langzeitreihen in der Deutschen Bucht bei Helgoland. Biologische Anstalt Helgoland.

Radach, G., Pätsch, J., Gekeller, J. and Herbig, K. 1995: Annual cycles of nutrients and chlorophyll in the North Sea. Berichte aus dem Zentrum für Meeres- und Klimaforschung, Reihe $B$. Ozeanographie 1, 1-172.

Reid, P.C., Lancelot, C., Gieskes, C.W.W., Hagmeier, E. and Weichart, G. 1990: Phytoplankton of the North Sea and its dynamics: a review. Netherlands Journal of Sea Research 26, 295-331.

Richardson, C.A., Crisp, D.J. and Runham, N.W. 1981: Factors influencing shell deposition during a tidal cycle in the intertidal bivalve Cerastoderma edule. Journal of Marine Biological Association of the United Kingdom 61, 465-76.

Ropes, J.W. 1985: Modern methods to age oceanic bivalves. Nautilus 99, 53-57.

SAS-Institute 2002: JMP statistics and graphics guide. SASInstitute Inc USA

Schöne, B.R., Oschmann, W., Rössler, J., Freye Castro, D.A., Houk, D.S., Kröncke, I., Dreyer, W., Janssen, R., Rumohr, H. and Dunca, E. 2003: North Atlantic Oscillation dynamics recorded in shells of a long-lived bivalve mollusk. Geology 31, 1037-40.

Schott, F. 1966: Der Oberflächensalzgehalt in der Nordsee. Ergänzungsheft Deutsche Hydrologische Zeitschrift A9, Deutsches Hydrographisches Institut, Hamburg 51, 113-32.

Sündermann, J., Hesse, J.K. and Beddig, S. 1999: Coastal mass and energy fluxes in the southeastern North Sea. Deutsche hydrographische Zeitschrift 51, 113-32.

Taylor, A.H. and Stephens, J.A. 1980: Seasonal and year-to-year variations in surface salinity at the nine North-Atlantic Ocean Weather Stations. Oceanologica Acta 3, 421-30.

Thompson, I., Jones, S.D. and Dreibelbis, D. 1980: Annual internal growth banding and life history of the ocean quahog Arctica islandica (Mollusca: Bivalvia). Marine Biology 57, 25-34.

Umweltbundesamt, Nationalparkverwaltung Niedersaechsisches Wattenmeer 1999: Umweltatlas Wattenmeer. Verlag Eugen Ulmer $\mathrm{GmbH} \& \mathrm{Co}, 200 \mathrm{pp}$.

Weidmann, C.R., Jones, G.A. and Lohmann, K.C. 1994: The longlived mollusc Arctica islandica: a new paleoceanographic tool for the reconstruction of bottom temperatures for the continental shelves of the northern north Atlantic Ocean. Journal Geophysical Research 99, 18305-14.

Witbaard, R. and Duineveld, G.C.A. 1990: Shell-growth of the bivalve Arctica islandica (L.), and its possible use for evaluating the status of the benthos in the subtidal North Sea. Basteria, 54, $63-74$.

Witbaard, R., Duineveld, G.C.A. and de Wilde, P.A.W.J. 1996: Growth variations in Arctica islandica L. (Bivalvia, Mollusca); a reflection of hydrography related food supply. Ices Journal of Marine Science 53, 981-87.

Witbaard, R., Franken, R. and Visser, B. 1997: Growth of juvenile Arctica islandica under experimantal conditions. Helgoländer Meeresuntersuchungen 51, 417-31.

Zettler, M.L., Bönsch, R. and Gosselck, F. 2001: Distribution, abundance and some population characteristics of the ocean quahog, Arctica islandica (Linnaeus, 1767), in the Mecklenburg Bight (Baltic Sea). Journal of Shellfish Research 20, 161-69. 